STUDIES IN ENGLISH LITERATURE

Volume XCVII 



\title{
THE THRONE AND
}

THE CHARIOT

\section{STUDIES IN MILTON'S \\ HEBRAISM}

\author{
by
}

KITTY COHEN

1975

MOUTON

THE HAGUE - PARIS 
(C) Copyright 1975

Mouton \& Co. B.V., Publishers, The Hague

No part of this book may be translated or reproduced in any form, by print, photoprint, microfilm, or any other means, without written permission from the publishers

This book was intended to appear in 1974, the three-hundredth anniversary of Milton's death and the publication of Paradise Lost in twelve books, and we regret that its publication was delayed

ISBN $902793293 \mathrm{X}$

Photoset in Malta by St. Paul's Press Ltd. Printed in The Netherlands by Intercontinental Graphics 
To the Memory of My Mother 
